\section{Two Cultivars of Oakleaf Hydrangea Respond to Ancymidol, Uniconazole, or Pinching}

\author{
Janet C. Cole ${ }^{1,4}$, Robert O. Brown ${ }^{2}$, and Mark E. Payton ${ }^{3}$
}

ADDITIONAL INDEX wORDs. growth regulator, Hydrangea quercifolia, nursery production

SUMMARY. Shearing is an important cultural practice for maintaining plant size and appearance during nursery crop production. However, oakleaf hydrangea (Hydrangea quercifolia) is susceptible to dieback after shearing. The objective of this study was to determine whether foliar or substrate surface applications of ancymidol or uniconazole can reduce plant growth of oakleaf hydrangea similar to pinching, which was used to simulate shearing. 'Alice' or 'Pee Wee' oakleaf hydrangea plants were treated in 2002 or 2006, respectively, with ancymidol or uniconazole as a substrate surface application at $0,1,2$, or $4 \mathrm{ppm}$; ancymidol as a foliar application at $0,25,50$, or $100 \mathrm{ppm}$; or uniconazole as a foliar application at $0,12.5,25$, or

$50 \mathrm{ppm}$. Both cultivars received the same plant growth regulator treatments in 2012, and a pinched control was included in the 2012 experiment. Ancymidol and uniconazole had limited and inconsistent effects on growth of 'Alice' and 'Pee Wee' plants regardless of application method. Uniconazole was more effective at controlling growth of 'Alice' in 2002 when the study was conducted from October through December than in 2012 when the study was conducted during a more typical growing season of May through September. Plants treated with either ancymidol or uniconazole by either application method usually grew more during the first 2 weeks after application than those that were pinched. During the remainder of the growing season, little difference in growth between pinched plants and growth regulatortreated plants occurred. At harvest in 2012, pinched 'Alice' plants had more leaves but a smaller leaf area per leaf than plants treated with growth regulators resulting in no difference in total leaf area or in leaf, shoot, or root dry weight among the treatments. 'Pee Wee' treated with uniconazole using either application method or uniconazole as a foliar application had fewer leaves than pinched plants.

A ncymidol and uniconazole are plant growth regulators that slow plant growth by inhibiting sterol and gibberellin biosynthesis (Henry, 1985; Shive and Sisler, 1976). These growth regulators have been shown to restrict height of several floricultural crops, including poinsettia [Euphorbia pulcherrima (Holcomb et al., 1983)], chrysanthemum [Dendranthema $\times$ grandiflorum (Barrett,

Approved for publication by the Director of the Oklahoma Agricultural Experiment Station. This research was supported under project OKL02324. The 2002 study was conducted as an undergraduate independent research project. Plants were provided by Greenleaf Nursery Co., Park Hill, OK. SePRO provided ancymidol and Valent Corporation provided uniconazole for this project. We thank Pamela Tauer, former Research Specialist, and Amber Hitchcock, Matt Withrow, Kelley Conaghan, Robyn Schutze, and Joseph Glennie, undergraduate students, for technical help in this project.

${ }^{1}$ Regents Professor, Department of Horticulture and Landscape Architecture, Oklahoma State University, Stillwater, OK 74078

${ }^{2}$ Former undergraduate student, Department of Horticulture and Landscape Architecture, Oklahoma State University, Stillwater, OK 74078

${ }^{3}$ Regents Service Professor, Statistics Department, Oklahoma State University, Stillwater, OK 74078

${ }^{4}$ Corresponding author. e-mail janet.cole@okstate.edu.
1982)], lily [Lilium speciosum (Bailey and Miller, 1989)], and several bedding plant species (Barrett and Nell, 1992).

Use of plant growth regulators during woody ornamental plant production is less common than in floriculture crop production. Several studies have tested nursery crop response to uniconazole (Frymire and Cole, 1992; Frymire and Henderson-Cole, 1992; Henderson and Nichols, 1991; Norcini and Knox, 1989; Warren, 1990; Warren et al., 1991). Woody plant response to growth regulators varies with environment, application rate and method, and species being treated. Recommendations for rate and timing of effective growth regulators for a variety of woody species are needed (Warren et al., 1991).

Oakleaf hydrangea is an important container crop for many nurseries in the southern and midwestern United States. It is used in the landscape as a border or as a solitary specimen plant. In commercial practice, shearing is required at least once or twice during the production cycle to produce a salable plant. After shearing, however, oakleaf hydrangea is susceptible to dieback, especially when excess moisture is present (P. Havenar, personal communication). A search of the literature revealed no reports regarding research on control of plant size of oakleaf hydrangea with growth regulators; however, uniconazole has been shown to reduce shoot length, stem dry weight, leaf area, and inflorescence dry weight of florists' hydrangea [Hydrangea macrophylla (Bailey, 1989)]. The objective of this research was to determine whether foliar or substrate surface applications of ancymidol or uniconazole, or pinching reduces plant growth of oakleaf hydrangea.

\section{Materials and methods}

2002 GreENHOUSE STUDY. Uniform rooted cuttings, about $30 \mathrm{~cm}$ in height, of 'Alice' oakleaf hydrangea were planted in l-gal containers on 26 Sept. in Stillwater, OK. The substrate consisted of aged pine bark:peat:sand (3:1:1 by volume) amended with 7.2 $\mathrm{lb} /$ yard $^{3} 17 \mathrm{~N}-3.6 \mathrm{P}-10 \mathrm{~K}$ controlledrelease fertilizer (Osmocote 17-7-12; Scotts, Marysville, $\mathrm{OH}), 1.5 \mathrm{lb} /$ yard $^{3}$ micronutrients (Micromax, Scotts) and $3 \mathrm{lb} /$ yard $^{3}$ dolomite. The pine bark particle size was considered coarse (63\% to $65 \%$ by volume of particles greater than $2.4 \mathrm{~mm}$ ). Plants were grown in a polyethylene-covered greenhouse under a long photoperiod obtained by a 2 -h night interruption with supplemental incandescent lighting (2400 to $0200 \mathrm{HR}$ ). The maximum

\begin{tabular}{llll}
\hline $\begin{array}{l}\text { Units } \\
\text { To convert U.S. to SI, } \\
\text { multiply by }\end{array}$ & U.S. unit & SI unit & $\begin{array}{l}\text { To convert SI to U.S., } \\
\text { multiply by }\end{array}$ \\
\hline 29.5735 & $\mathrm{fl} \mathrm{oz}$ & $\mathrm{mL}$ & 0.0338 \\
2.54 & inch(es) & $\mathrm{cm}$ & 0.3937 \\
25.4 & inch $(\mathrm{es})$ & $\mathrm{mm}$ & 0.0394 \\
6.4516 & inch $^{2}$ & $\mathrm{~cm}^{2}$ & 0.1550 \\
0.5933 & lb/yard & $\mathrm{kg} \cdot \mathrm{m}^{-3}$ & 1.6856 \\
28.3495 & oz & $\mathrm{g}$ & 0.0353 \\
1 & $\mathrm{ppm}$ & $\mathrm{mg} \cdot \mathrm{L}^{-1}$ & 1 \\
$\left({ }^{\circ} \mathrm{F}-32\right) \div 1.8$ & ${ }^{\circ} \mathrm{F}$ & ${ }^{\circ} \mathrm{C}$ & $\left({ }^{\circ} \mathrm{C} \times 1.8\right)+32$ \\
& & &
\end{tabular}


photosynthetic photon flux (PPF) was $800 \mu \mathrm{mol} \cdot \mathrm{m}^{-2} \cdot \mathrm{s}^{-1}$ at plant height, and maximum/minimum air temperatures were $32 / 18{ }^{\circ} \mathrm{C}$. Plants were watered as needed and received supplemental weekly fertilization with $200 \mathrm{mg} \cdot \mathrm{L}^{-1} \mathrm{~N}$ as $20 \mathrm{~N}-4.3 \mathrm{P}-16.6 \mathrm{~K}$ water-soluble fertilizer (Peters 20-10-20 PLS, Scotts) and applications of $750 \mathrm{mg} \cdot \mathrm{L}^{-1}$ soluble micronutrients (Soluble Trace Element Mix, Scotts) every $10 \mathrm{~d}$.

On 15 Oct., ancymidol (A-Rest; SePRO, Carmel, IN) or uniconazole (Sumagic; Valent, Walnut Creek, CA) was applied consistently across the substrate surface around the plant in $50-\mathrm{mL}$ aliquots at concentrations of $0,1,2$, or $4 \mathrm{ppm}$; or ancymidol was applied as a foliar spray with a pumptype spray bottle at $0,25,50$, or 100 ppm; or uniconazole was applied as a foliar spray at $0,12.5,25$, or $50 \mathrm{ppm}$. Label rates at the time of the study were 26 to $132 \mathrm{ppm}$ ancymidol for foliar sprays, 1 to 4 ppm ancymidol for substrate drenches, 10 to $50 \mathrm{ppm}$ uniconazole for foliar sprays to woody landscape ornamentals, or 1 to $2 \mathrm{ppm}$ uniconazole for substrate drenches on woody landscape ornamentals. All of the solution applied to the substrate surface was absorbed by the substrate (no leaching). About $4 \mathrm{~mL}$ of solution was applied to each plant in foliar treatments. The substrate surface of plants receiving foliar sprays was covered with aluminum foil before spraying to assure that no chemical would be absorbed by the substrate. The foil was removed when the foliage had dried. All treatments were applied in the early morning (between 0800 and $1000 \mathrm{HR}$ ) to reduce rapid evaporation from heat and wind. Foliar treatments dried in about $45 \mathrm{~min}$.

Plants were not irrigated for $24 \mathrm{~h}$ after application of the plant growth regulators. Then plants were hand watered with a hose using tap water.

Plant heights were measured from the substrate surface to the top of the tallest shoot and canopy widths (an average of two perpendicular measurements) were measured at planting and every 2 weeks for the 6-week duration of the study. Plant growth in height and canopy width between measurement dates was calculated as $\mathrm{G}=\mathrm{M}_{\mathrm{E}}-$ $M_{0}$, where $G=$ growth of the selected measurement parameter, $\mathrm{M}_{\mathrm{E}}=$ measurement at the end of the measurement interval, and $\mathrm{M}_{0}=$ measurement at the beginning of the measurement interval. At the end of the study, plants were harvested and shoots (including stems and leaves) and roots were dried at $45^{\circ} \mathrm{C}$ for $7 \mathrm{~d}$ and weighed. Root to shoot ratios ( $\mathrm{R} / \mathrm{S}$ ratios) were calculated as root dry weight/shoot dry weight.

2006 Shadehouse study. A similar experiment was conducted except 'Pee Wee' was used instead of 'Alice'. Plants that were about $25 \mathrm{~cm}$ in height were planted on 27 Apr. in Stillwater, OK and placed in a shadehouse with $40 \%$ shadecloth under natural daylengths and received a maximum PPF of $1350 \mu \mathrm{mol} \cdot \mathrm{m}^{-2} \cdot \mathrm{s}^{-1}$. They were irrigated with about $l$ inch of tap water daily using overhead sprinkler irrigation. Plants received no liquid fertilization, but controlledrelease fertilizers, were incorporated into the substrate as described above. Plants were treated with growth regulators on 11 May; and height and canopy width were measured at planting, then at $2,4,8,12,16$, and 20 weeks after treatment. Plants were harvested on 7 Oct. Daily high temperatures during 2006 averaged $90.2^{\circ} \mathrm{F}$ with a maximum high temperature of $107^{\circ} \mathrm{F}$.

2012 Shadehouse Study. The 2006 study was repeated using both 'Alice' and 'Pee Wee' with the following exceptions: Plants were planted on 5 Apr. and treated on 17 May. Plant height and canopy width were measured at planting, then at $2,4,8,12$, and 16 weeks after treatment. Besides the plant growth regulator treatments, a pinched treatment was included. The pinch treatment consisted of pinching the growing points of plants back to the node below the growing point on the same date as growth regulators were applied to other treatments. This pinch simulated a light shearing that would be done commercially (P. Havenar, personal communication). Plants were harvested beginning on 6 Sept. (16 weeks after treatment) and leaf number; total plant leaf area (LI-3100 leaf area meter; LI-COR, Lincoln, NE); and leaf, stem, and root dry weight were determined. Leaf area per leaf was calculated as total leaf area/leaf number. $\mathrm{R} / \mathrm{S}$ ratio was calculated as root dry weight/(stem dry weight + leaf dry weight). Daily high temperatures averaged $91.2^{\circ} \mathrm{F}$ with a maximum high temperature of $113^{\circ} \mathrm{F}$.

STATISTICS. A randomized complete block design with 10 single-plant replications in 2002 and seven singleplant replications in 2006 and 2012 was used. Sixteen treatments (two growth regulators, two application methods, and four rates) were used in 2002 and 2006. Data were analyzed using the GLM procedure in SAS (version 9.1; SAS Institute, Cary, NC) and trend analyses were performed using orthogonal contrasts within each growth regulator and application method. Seventeen treatments were applied to each of two cultivars in 2012 (two growth regulators, two application methods, and four rates, and a pinched control). Data were analyzed using the MIXED procedure in SAS (version 9.3). Trend analyses were performed using orthogonal contrasts within each growth regulator and application method and pairwise $t$ tests were used to determine differences between the pinched plants and each growth regulator treatment.

\section{Results}

2002 Greenhouse study. Ancymidol did not affect growth in height or canopy width of 'Alice' plants during any growth interval when applied as either foliar application or substrate surface application (data not presented). Ancymidol applied as a foliar application or substrate surface application also did not affect shoot or root dry weight or $\mathrm{R} / \mathrm{S}$ ratio.

The foliar application of uniconazole decreased growth in plant height and canopy width linearly as concentration increased during the first 2 weeks after application (Table 1 ). Growth in plant height was unaffected between 2 and 4 weeks after application, but canopy width decreased linearly as uniconazole concentration increased during this period. Neither growth in height nor growth in canopy width was affected between 4 and 6 weeks after uniconazole foliar application. Shoot and root dry weight decreased linearly as uniconazole concentration increased with the foliar application, but $\mathrm{R} / \mathrm{S}$ ratio was unaffected and was 0.15 .

Uniconazole applied to the substrate surface linearly decreased growth in height and canopy width the first 2 weeks after application (Table 1 ). Growth in canopy width decreased linearly between 2 and 4 weeks after uniconazole substrate surface application, but height growth was unaffected during this period. A curvilinear 
Table 1. Growth in height and canopy width between measurement dates in 2002 and root and shoot dry weight at harvest of 'Alice' oakleaf hydrangea treated with uniconazole as a substrate surface application or foliar application $(n=10)$.

\begin{tabular}{|c|c|c|c|c|c|c|c|c|}
\hline \multirow[b]{3}{*}{ Uniconazole concn $(\mathrm{ppm}) \mathrm{z}$} & \multicolumn{6}{|c|}{ Plant growth $(\mathrm{cm}) \mathrm{y}$} & & \\
\hline & \multicolumn{2}{|c|}{ 0-2 WATx } & \multicolumn{2}{|c|}{ 2-4 WAT } & \multicolumn{2}{|c|}{ 4-6 WAT } & \multicolumn{2}{|c|}{ Dry wt (g)z } \\
\hline & Ht & Width & $\overline{\mathrm{Ht}}$ & $\overline{\text { Width }}$ & $\mathrm{Ht}$ & Width & Shoot & Root \\
\hline 0 & 6.5 & 12.8 & 5.3 & 13.3 & 11.8 & 15.5 & 22.8 & 3.2 \\
\hline 12.5 & 4.9 & 9.6 & 5.4 & 11.3 & 11.2 & 17.0 & 20.1 & 2.7 \\
\hline 25 & 5.1 & 9.8 & 5.2 & 12.0 & 11.0 & 15.6 & 18.6 & 2.6 \\
\hline Quadratic & NS & NS & NS & NS & NS & NS & NS & NS \\
\hline \multicolumn{9}{|c|}{ Uniconazole substrate drench application } \\
\hline 0 & 6.4 & 11.3 & 4.2 & 11.1 & 9.5 & 15.1 & 19.5 & 2.9 \\
\hline 1 & 5.5 & 9.9 & 4.7 & 10.4 & 11.5 & 17.4 & 19.3 & 2.8 \\
\hline
\end{tabular}

Ns, $, * *, * * *$ Not significant or significant at $P \leq 0.05,0.01$, or 0.001 , respectively.

${ }^{2} 1 \mathrm{ppm}=1 \mathrm{mg} \cdot \mathrm{L}^{-1}, 1 \mathrm{~g}=0.0353 \mathrm{oz}$.

y Plant growth in height and canopy width between measurement dates was calculated as $G=M_{E}-M_{0}$, where $G=$ growth of the selected measurement parameter, $M_{E}=$ measurement at the end of the measurement interval, and $\mathrm{M}_{0}=$ measurement at the beginning of the measurement interval; $1 \mathrm{~cm}=0.3937$ inch.

${ }^{x}$ WAT $=$ weeks after treatment.

relationship existed between growth in height and uniconazole concentration such that plants receiving 1 or 2 ppm grew more than control plants, but plants receiving 4 ppm grew less in height between 4 and 6 weeks after application. Growth in canopy width was unaffected between 4 and 6 weeks after application when uniconazole was applied to the substrate. Shoot and root dry weight decreased linearly as uniconazole concentration increased when applied to the substrate surface, but $\mathrm{R} / \mathrm{S}$ ratio was unaffected.

2006 STUdy. Ancymidol foliar application did not affect growth in height or canopy width of 'Pee Wee' during any measurement period (data not presented). Shoot dry weight and $\mathrm{R} / \mathrm{S}$ ratio were unaffected by ancymidol foliar application. Root dry weight responded inconsistently $(P \leq 0.05)$ as ancymidol foliar application rate increased such that dry weights of plants receiving 25 or $100 \mathrm{ppm}$ were larger (10.2 or 7.9 g, respectively) than untreated control plants $(6.3 \mathrm{~g})$, whereas those of plants receiving $50 \mathrm{ppm}$ were smaller $(3.7 \mathrm{~g})$ than control plants $(6.3 \mathrm{~g})$. Similarly, ancymidol applied to the substrate surface did not affect growth in height or canopy width of 'Pee Wee' during any measurement period (data not presented). Shoot and root dry weight and $\mathrm{R} / \mathrm{S}$ ratio were unaffected by ancymidol substrate application.
Uniconazole applied as a foliar application had an inconsistent affect $(P \leq 0.05)$ on growth in plant height $(2.4,0.8,2.5$, and $2.8 \mathrm{~cm}$ for $0,12.5$, 25 , and $50 \mathrm{ppm}$, respectively) of 'Pee Wee' during the first 2 weeks after application and on growth in canopy width $[4.2,1.8,3.6$, and $1.9 \mathrm{~cm}$ for 0 , $12.5,25$, and $50 \mathrm{ppm}$, respectively $(P \leq$ $0.05)$ ] between 2 and 4 weeks after application. Growth in height and width were unaffected by uniconazole foliar application at any other time, and shoot dry weight, root dry weight, and $\mathrm{R} / \mathrm{S}$ ratio were unaffected (data not presented). Uniconazole applied to the substrate did not affect any measurement parameter (data not presented) except $R / S$ ratio decreased linearly from 0.46 at $0 \mathrm{ppm}$ (control) to 0.22 at $4 \mathrm{ppm}(P \leq 0.05)$.

2012 STUDY. Ancymidol applied to the foliage or as a substrate drench did not affect growth of 'Alice' at any time during the 2012 growing season (Table 2). 'Alice' plants treated with ancymidol regardless of application method grew more during the first 2 weeks after application than pinched plants, but few differences in growth occurred during the remainder of the growing season between plants treated with ancymidol as a foliar application or a substrate drench compared with pinched plants.

The uniconazole foliar application resulted in a linear increase in height and width growth of 'Alice' plants from 12 to 16 weeks after application as concentration increased. Uniconazole applied as a substrate drench resulted in a linear decrease in width of 'Alice' plants as uniconazole concentration increased from the date of application to 2 weeks after application, but a linear increase in plant width from 2 to 4 weeks after application. Uniconazole substrate drench resulted in a curvilinear response of plant height such that plants were tallest with the tap water control, shortest with the 2 ppm concentration and intermediate in height growth with 1 and $4 \mathrm{ppm}$. Similar to plants treated with ancymidol, plants treated with uniconazole grew more during the first 2 weeks after treatment than those that were pinched, but few differences in growth between uniconazole-treated and pinched plants occurred during the remainder of the growing season.

At harvest, no trends occurred between any of the parameters measured and concentration of either ancymidol or uniconazole applied to the foliage (Table 3 ). When ancymidol was applied as a substrate drench, a curvilinear relationship occurred between stem dry weight and ancymidol concentration such that stem dry weight increased as ancymidol concentration increased from 0 to $2 \mathrm{ppm}$ but then dry weight was lower at $4 \mathrm{ppm}$. Uniconazole applied as a substrate 
Table 2. Growth in height and canopy width between measurement dates in 2012 of 'Alice' oakleaf hydrangea that were pinched or treated with ancymidol or uniconazole as a substrate surface application or foliar application $(n=7)$.

\begin{tabular}{|c|c|c|c|c|c|c|c|c|c|c|}
\hline \multirow[b]{3}{*}{ Pinch or concn $(\mathrm{ppm}) \mathrm{z}$} & \multicolumn{10}{|c|}{ Plant growth $(\mathrm{cm}) \mathrm{y}$} \\
\hline & \multicolumn{2}{|c|}{ 0-2 WATx } & \multicolumn{2}{|c|}{ 2-4 WAT } & \multicolumn{2}{|c|}{ 4-8 WAT } & \multicolumn{2}{|c|}{ 8-12 WAT } & \multicolumn{2}{|c|}{ 12-16 WAT } \\
\hline & Ht & $\overline{\text { Width }}$ & Ht & $\overline{\text { Width }}$ & Ht & $\overline{\text { Width }}$ & Ht & Width & Ht & Width \\
\hline \multicolumn{11}{|c|}{ Ancymidol foliar application } \\
\hline 0 & $11.9^{*}$ & $10.8^{\mathrm{Ns}}$ & $4.6^{\mathrm{NS}}$ & $0.0^{\mathrm{Ns}}$ & $8.6^{\mathrm{Ns}}$ & $10.1^{\mathrm{NS}}$ & $7.4^{\mathrm{Ns}}$ & $2.9^{\mathrm{Ns}}$ & $6.0^{\mathrm{Ns}}$ & $-0.4^{\mathrm{NS} \mathrm{w}}$ \\
\hline 100 & $12.3^{*}$ & $10.0^{\mathrm{Ns}}$ & $2.9^{\mathrm{Ns}}$ & $2.7^{\mathrm{Ns}}$ & $8.5^{\mathrm{Ns}}$ & $6.1^{\mathrm{Ns}}$ & $6.1^{\mathrm{Ns}}$ & $5.2^{\mathrm{Ns}}$ & $8.0^{\mathrm{Ns}}$ & $0.0^{\mathrm{Ns}}$ \\
\hline Linear & NS & NS & NS & NS & NS & NS & NS & NS & NS & NS \\
\hline Quadratic & NS & NS & NS & NS & NS & NS & NS & NS & NS & NS \\
\hline \multicolumn{11}{|c|}{ Ancymidol substrate drench application } \\
\hline Linear & NS & NS & NS & NS & NS & NS & NS & NS & NS & NS \\
\hline Quadratic & NS & NS & NS & NS & NS & NS & NS & NS & NS & NS \\
\hline \multicolumn{11}{|c|}{ Uniconazole foliar application } \\
\hline 0 & $11.0^{*}$ & $9.5^{\mathrm{Ns}}$ & $4.3^{\mathrm{Ns}}$ & $0.8^{\mathrm{Ns}}$ & $8.9^{\mathrm{Ns}}$ & $10.2^{\mathrm{Ns}}$ & $6.4^{\mathrm{Ns}}$ & $3.1^{\mathrm{Ns}}$ & $7.2^{\mathrm{Ns}}$ & $-2.6^{*}$ \\
\hline 12.5 & $8.6^{*}$ & $8.9^{\mathrm{NS}}$ & $6.4^{\mathrm{NS}}$ & $0.9^{\mathrm{Ns}}$ & $8.8^{\mathrm{Ns}}$ & $10.8^{\mathrm{NS}}$ & $5.6^{\mathrm{Ns}}$ & $2.7^{\mathrm{Ns}}$ & $11.0^{\mathrm{NS}}$ & $-0.4^{\mathrm{NS}}$ \\
\hline 25 & $10.4^{*}$ & $9.3^{\mathrm{Ns}}$ & $4.4^{\mathrm{NS}}$ & $0.0^{\mathrm{Ns}}$ & $5.9 *$ & $7.3^{\mathrm{NS}}$ & $6.6^{\mathrm{Ns}}$ & $5.1^{\mathrm{NS}}$ & $8.6^{\mathrm{Ns}}$ & $0.1^{\mathrm{NS}}$ \\
\hline 50 & $10.5^{*}$ & $10.5^{\mathrm{Ns}}$ & $4.9^{\mathrm{Ns}}$ & $0.3^{\mathrm{NS}}$ & $8.3^{\mathrm{Ns}}$ & $6.5^{\mathrm{NS}}$ & $5.5^{\mathrm{Ns}}$ & $2.7^{\mathrm{Ns}}$ & $11.7^{*}$ & $4.0^{\mathrm{Ns}}$ \\
\hline Linear & NS & NS & NS & NS & NS & NS & NS & NS & * & $*$ \\
\hline Quadratic & NS & NS & NS & NS & NS & NS & NS & NS & NS & NS \\
\hline
\end{tabular}

Ns, $*, * * * * *$ Not significant or significant at $P \leq 0.05,0.01$, or 0.001 , respectively, relative to pinched treatment or in respect to linear or quadratic responses.

${ }^{2} 1 \mathrm{ppm}=1 \mathrm{mg} \cdot \mathrm{L}^{-1}$

'Plant growth in height and canopy width between measurement dates was calculated as $G=M_{E}-M_{0}$, where $G=$ growth of the selected measurement parameter, $M_{E}=$ measurement at the end of the measurement interval, and $\mathrm{M}_{0}=$ measurement at the beginning of the measurement interval. $1 \mathrm{~cm}=0.3937$ inch.

${ }^{x}$ WAT $=$ weeks after treatment.

wegative values for growth in height and width are due to human error in selecting tallest or widest points of the plant to measure from one measurement time to the next.

No plant dieback was observed at any time during the study.

drench resulted in a linear increase in leaf dry weight as concentration increased.

When ancymidol- and uniconazoletreated 'Alice' plants were compared with pinched plants at harvest, pinched plants had more leaves than almost any plant treated with either growth regulator by either application method at any rate (Table 3 ). While the number of leaves was greater in the pinched treatment, leaf area per leaf of pinched plants was smaller than that of many of the plants treated with either growth regulator by either application method at any rate. Total plant leaf area, and leaf, stem, and root dry weight did not differ between pinched plants and those treated with either growth regulator or application method at any rate.

Similar to 'Alice', ancymidol had little effect on growth of 'Pee Wee' plants (Table 4). As ancymidol application rate increased, growth in height of 'Pee Wee' plants from 12 to 16 weeks after treatment responded curvilinearly such that the largest plants were in the tap water control treatment, and growth decreased at 25 and $50 \mathrm{ppm}$, but was intermediate at 100 ppm. Ancymidol or uniconazole applied as a substrate drench did not affect growth in height or width of
'Pee Wee' plants at any time during the growing season. Uniconazole applied as a foliar application resulted in a linear decrease in plant growth in height from 8 to 12 weeks after treatment as uniconazole foliar application rate increased.

Similar to 'Alice', pinched 'Pee Wee' plants grew less in height from the treatment date to 2 weeks after treatment than ancymidol foliar or substrate drench applications or uniconazole foliar applications at any rate (Table 4). Plants receiving uniconazole as a substrate drench application at 1,2 , or 4 ppm did not differ from the pinched plants during this same 
Table 3. Number of leaves; total plant leaf area; leaf area per leaf; leaf, stem, and root dry weight; and root to shoot (R/S) ratio of 'Alice' oakleaf hydrangea that were pinched or treated with ancymidol or uniconazole as a foliar application or substrate drench at several concentrations in $2012(n=7)$.

\begin{tabular}{|c|c|c|c|c|c|c|c|}
\hline $\begin{array}{l}\text { Pinch or Concn } \\
(\mathrm{ppm})^{\mathrm{z}}\end{array}$ & Leaves (no.) & $\begin{array}{c}\text { Total leaf area } \\
\left(\mathrm{cm}^{2}\right)^{\mathrm{z}}\end{array}$ & $\begin{array}{l}\text { Leaf area per leaf } \\
\left(\mathrm{cm}^{2}\right)\end{array}$ & Leaf & $\begin{array}{l}\text { Dry wt }(g)^{\mathrm{z}} \\
\text { Stem }\end{array}$ & Root & $\mathrm{R} / \mathrm{S}$ ratio \\
\hline Pinch & 136 & 5210.2 & 38.5 & 36.3 & 25.6 & 13.6 & 0.54 \\
\hline \multicolumn{8}{|c|}{ Ancymidol foliar application } \\
\hline 0 & $88 * * *$ & $4636.3^{\mathrm{Ns}}$ & $54.9^{*}$ & $35.4^{\mathrm{Ns}}$ & $23.5^{\mathrm{Ns}}$ & $14.2^{\mathrm{Ns}}$ & $0.60^{\mathrm{Ns}}$ \\
\hline 25 & $88 * * *$ & $4711.7^{\mathrm{Ns}}$ & $54.9^{*}$ & $36.0^{\mathrm{Ns}}$ & $22.3^{\mathrm{NS}}$ & $14.9^{\mathrm{Ns}}$ & $0.68^{*}$ \\
\hline Linear & NS & NS & NS & NS & NS & NS & NS \\
\hline Quadratic & NS & NS & NS & NS & NS & NS & NS \\
\hline \multicolumn{8}{|c|}{ Ancymidol substrate drench application } \\
\hline 0 & $91 * * *$ & $4841.5^{\mathrm{NS}}$ & $53.6^{* *}$ & $36.0^{\mathrm{Ns}}$ & $21.3^{\mathrm{Ns}}$ & $14.6^{\mathrm{NS}}$ & $0.72 *$ \\
\hline 1 & $86^{* * *}$ & $4653.6^{\mathrm{Ns}}$ & 54.4 ** & $33.5^{\mathrm{Ns}}$ & $24.0^{\mathrm{NS}}$ & $14.8^{\mathrm{Ns}}$ & $0.59^{\mathrm{Ns}}$ \\
\hline Quadratic & NS & NS & NS & NS & * & NS & NS \\
\hline \multicolumn{8}{|c|}{ Uniconazole foliar application } \\
\hline 0 & $97^{*}$ & $4675.2^{\mathrm{Ns}}$ & $50.2^{\mathrm{Ns}}$ & $36.1^{\mathrm{Ns}}$ & $24.0^{\mathrm{Ns}}$ & $13.2^{\mathrm{Ns}}$ & $0.56^{\mathrm{Ns}}$ \\
\hline 12.5 & $96 *$ & $4971.7^{\mathrm{Ns}}$ & $54.1^{*}$ & $39.0^{\mathrm{Ns}}$ & $24.9^{\mathrm{Ns}}$ & $13.6^{\mathrm{Ns}}$ & $0.55^{\mathrm{Ns}}$ \\
\hline 25 & $110^{\mathrm{Ns}}$ & $4514.5^{\mathrm{Ns}}$ & $44.0^{\mathrm{Ns}}$ & $34.6^{\mathrm{Ns}}$ & $22.9^{\mathrm{NS}}$ & $13.8^{\mathrm{Ns}}$ & $0.62^{\mathrm{Ns}}$ \\
\hline 50 & $94^{*}$ & $4998.8^{\mathrm{Ns}}$ & $57.2 * *$ & $39.4^{\mathrm{Ns}}$ & $24.6^{\mathrm{NS}}$ & $16.2^{\mathrm{Ns}}$ & $0.65^{\mathrm{Ns}}$ \\
\hline Linear & NS & NS & NS & NS & NS & NS & NS \\
\hline Quadratic & NS & NS & NS & NS & NS & NS & NS \\
\hline \multicolumn{8}{|c|}{ Uniconazole substrate drench application } \\
\hline 0 & $84 * * *$ & $4496.2^{\mathrm{Ns}}$ & $57.1 * *$ & $32.2^{\mathrm{Ns}}$ & $22.5^{\mathrm{Ns}}$ & $12.7^{\mathrm{Ns}}$ & $0.60^{\mathrm{Ns}}$ \\
\hline
\end{tabular}

Ns, $*, * *, * * *$ Not significant or significant at $P \leq 0.05,0.01$, or 0.001 , respectively, relative to pinched treatment or in respect to linear or quadratic responses.

${ }^{\mathrm{z}} 1 \mathrm{ppm}=1 \mathrm{mg} \cdot \mathrm{L}^{-1}, 1 \mathrm{~cm}^{2}=0.1550$ inch $^{2}, 1 \mathrm{~g}=0.0353 \mathrm{oz}$.

period. Plants receiving the substrate drench application at most rates grew less in height from 4 to 8 weeks after treatment than pinched plants, but few other differences in growth occurred between plant growth regulatortreated plants and pinched plants during the growing season.

At harvest, total plant leaf area and stem and root dry weight of 'Pee Wee' decreased curvilinearly as ancymidol foliar application increased. No trends occurred in any parameter measured at harvest with ancymidol substrate drench application. Uniconazole applied as either a foliar application or substrate drench resulted in a linear decrease in $\mathrm{R} / \mathrm{S}$ ratio. 'Pee Wee' plants treated with ancymidol regardless of application method or uniconazole as a foliar application had fewer leaves than pinched 'Pee Wee' plants at harvest (Table 5). Leaf area per plant was lower on plants receiving ancymidol at 25 or 50 ppm as a foliar application or ancymidol at 0,1 , or 2 ppm as a substrate drench than for pinched plants. 'Pee Wee' plants in the uniconazole control foliar treatment (tap water) or those receiving 1,2 , or 4 ppm as a substrate drench also had smaller leaf areas than pinched plants. Leaf area per leaf was greater with ancymidol as a foliar application at 0 or 100 ppm or at any rate as a substrate drench than pinched plants. In contrast, uniconazole only affected leaf area per leaf compared with pinched plants when it was applied as a foliar application at $12.5 \mathrm{ppm}$. R/S ratio was greater on plants receiving ancymidol as a substrate drench at $2 \mathrm{ppm}$, uniconazole foliar application control (tap water), or uniconazole as a substrate drench at 0 or 2 ppm compared with pinched plants.

\section{Discussion}

Current commercial practice in production of oakleaf hydrangea is to lightly shear the plants periodically to maintain plant size (P. Havenar, personal communication). After pruning, buds below the cut break and generally will produce new branches resulting in a more full plant (Davidson et al., 2000). In this study, pinching resulted in a greater number of leaves than most growth regulator treatments in both cultivars (Tables 3 and 5 ). The presence of additional leaves and branching is desirable because consumers prefer a full, well-branched plant rather than a more sparse plant. The disadvantages to shearing and pinching are the costs because of the 
Table 4. Growth in height and canopy width between measurement dates in 2012 of 'Pee Wee' oakleaf hydrangea that were pinched or treated with ancymidol or uniconazole as a substrate surface application or foliar application $(n=7)$.

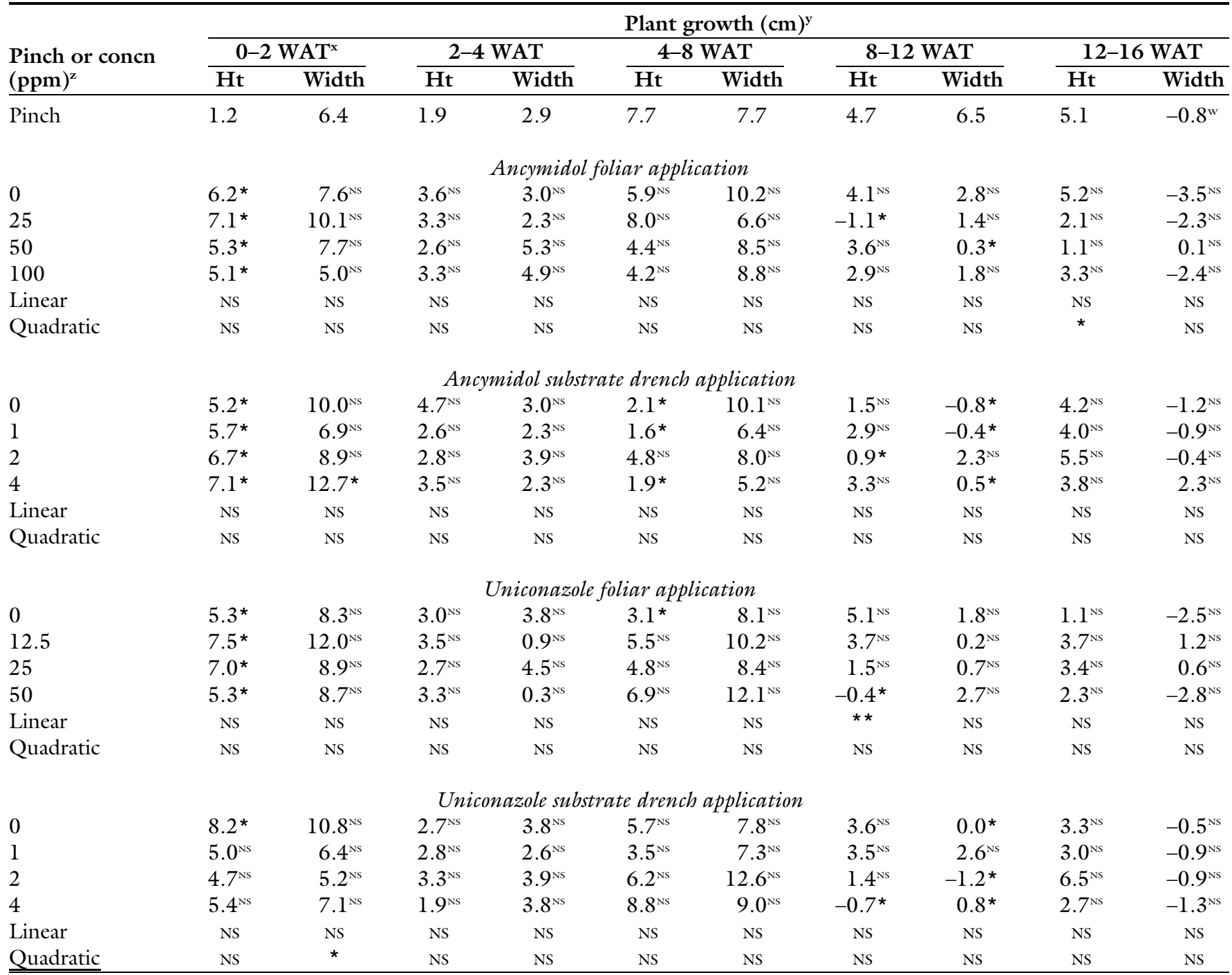

Ns, $*, * * * * *$ Not significant or significant at $P \leq 0.05,0.01$, or 0.001 , respectively relative to pinched treatment or in respect to linear or quadratic responses.

${ }^{\mathrm{z}} \mathrm{l} \mathrm{ppm}=1 \mathrm{mg} \cdot \mathrm{L}^{-1}$

'Plant growth in height and canopy width between measurement dates was calculated as $G=M_{E}-M_{0}$ where $G=$ growth of the selected measurement parameter, $M_{E}=$ measurement at the end of the measurement interval, and $\mathrm{M}_{0}=$ measurement at the beginning of the measurement interval; $1 \mathrm{~cm}=0.3937$ inch .

${ }^{x}$ WAT $=$ weeks after treatment.

wegative values for growth in height and width are due to human error in selecting tallest or widest points of the plant to measure from one measurement time to the next. No plant dieback was observed at any time during the study.

labor involved and the dieback in sheared plants as noted by the growers. No dieback was observed in this study in 2012 likely because shearing was simulated by pinching the growing point, leaving a clean cut with no bruising or tearing of the stems below the cut as might occur with mechanical shearing in a nursery.

An alternative to pinching might be the use of plant growth regulators if an effective chemical and method of application can be identified. In this study, ancymidol had little effect on either cultivar in any experiment. Ancymidol has been effective at reducing plant growth of several floriculture species when applied either to the foliage or to the substrate (Barrett, 1982; Frank and Day, 1976; Murray et al., 1986; Snell and Eysell, 1974; Wulster and Gianfagna, 1991). Research has shown that ancymidol is not as effective when applied as a substrate application if the substrate contains pine bark (Barrett, 1982; Bonamino and Larson, 1978; Tschabold et al., 1975). Pine bark was a large component of the substrate in this study, and could have reduced effectiveness of ancymidol in regulating plant growth in substrate applications; however, no differences in growth were apparent regardless of ancymidol application method or cultivar. Use of pine bark in growth substrate is a common practice in the nursery industry and not likely to be changed to increase the effectiveness of plant growth regulators.

In contrast, uniconazole, regardless of application method, reduced growth of 'Alice' during several measurement intervals and reduced shoot and root dry weights in 2002 . It was not as effective at reducing growth of 'Alice' in 2012, likely because of the different growing environment and shorter growing time since the plants were grown from October through December in a greenhouse in 2002 and during a typical growing season in a 
Table 5. Number of leaves, total plant leaf area, leaf area per leaf, leaf, stem, and root dry weight, and root to shoot (R/S) ratio of 'Pee Wee' oakleaf hydrangea that were pinched or treated with ancymidol or uniconazole as a foliar application or substrate drench at several concentrations in $2012(n=7)$.

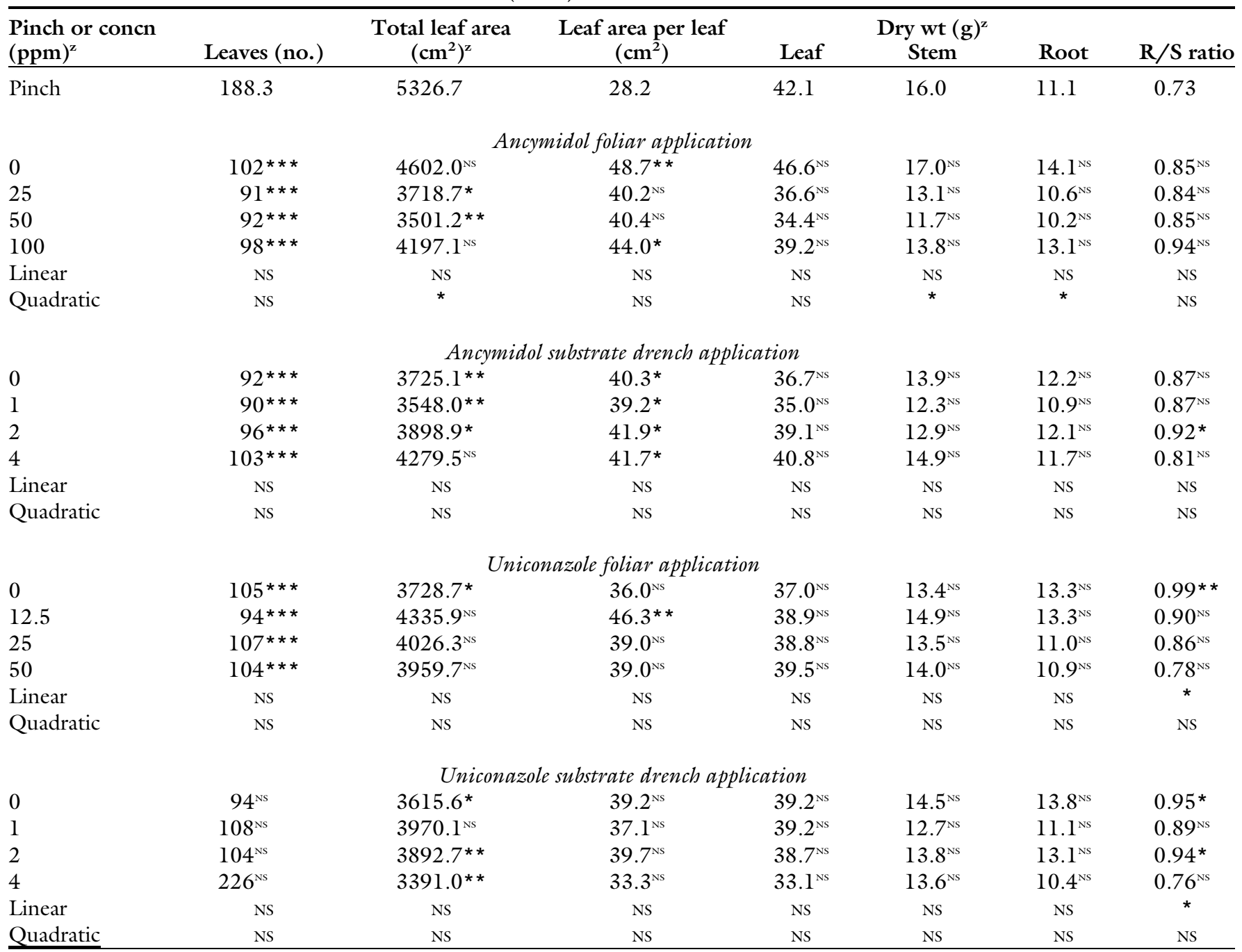

Ns, $*, * *, * * *$ Not significant or significant at $P \leq 0.05,0.01$, or 0.001 , respectively, relative to pinched treatment or in respect to linear or quadratic responses.

${ }^{\mathrm{z}} 1 \mathrm{ppm}=1 \mathrm{mg} \cdot \mathrm{L}^{-1}, 1 \mathrm{~cm}^{2}=0.1550$ inch $^{2}, 1 \mathrm{~g}=0.0353 \mathrm{oz}$.

shadehouse from April to September in 2012. Thus, daylengths, light intensities, temperatures, and fertilization regimes were different between the studies in 2002 and 2012. Uniconazole, however, had little effect on growth of 'Pee Wee' in 2006 or 2012. 'Pee Wee' is a smaller cultivar than 'Alice'. Because 'Pee Wee' has less aggressive growth than 'Alice', growth regulators may not be as effective in reducing growth of 'Pee Wee' as 'Alice'. Woody species have been shown to respond differently to various concentrations of uniconazole. Substrate drench applications of uniconazole reduced pyracantha (Pyracantha coccinea 'Lalandei') leaf area and leaf, stem, and root dry weight, but foliar applications had little effect on plant growth (Frymire and Henderson-Cole, 1992). Similarly, height, width, leaf area per plant, and dry weights of pyracantha, photinia (Photinia $\times$ fraseri), and dwarf Burford holly (Ilex cornuta 'Burfordii Nana') decreased as uniconazole substrate drench rate increased (Frymire and Cole, 1992). Foliar applications were less effective than drenches at reducing growth of pyracantha and photinia, and holly did not respond to the foliar treatment. Although plant growth can be reduced with uniconazole in some species, a decline in plant quality has also been noted in species such as photinia and holly (Frymire and Cole, 1992). In the present study, no changes in plant quality were observed with uniconazole application.

Based on this study, ancymidol and uniconazole had limited effectiveness in reducing growth of 'Alice' or 'Pee Wee' oakleaf hydrangea. Pinching generally resulted in plants with more leaves than, but similar total leaf area to, plants receiving ancymidol or uniconazole as either a foliar application or substrate drench application. From this study, we recommend that growers continue the practice of shearing oakleaf hydrangea during production rather than applying either ancymidol or uniconazole at the rates tested.

\section{Literature cited}

Bailey, D.A. 1989. Uniconazole effects on forcing of florists' hydrangeas. HortScience 24:518.

Bailey, D.A. and W.B. Miller. 1989. Response of oriental hybrid lilies to ancymidol and uniconazole. HortScience 24:519. 
Barrett, J.E. 1982. Chrysanthemum height control by ancymidol, PP333, and EL-500 dependent on medium composition. HortScience 17:896-897.

Barrett, J.E. and T.A. Nell. 1992. Efficacy of paclobutrazol and uniconazole on four bedding plant species. HortScience 27: 896-897.

Bonamino, V.P. and R.A. Larson. 1978. Influence of potting media, temperature, and concentration of ancymidol on growth of Chrysanthemum morifolium Ramat. J. Amer. Soc. Hort. Sci. 103:752-756.

Davidson, H., R. Mecklenburg, and C. Peterson. 2000. Nursery management administration and culture. 4th ed. PrenticeHall, Upper Saddle River, N.J.

Frank, R. and E.W. Day. 1976. Ancymidol, p. 475-482. In: G. Zweig (ed.). Analytical methods for pesticides, plant growth regulators, \& food additives. Academic Press, Waltham, MA.

Frymire, R.M. and J.C. Cole. 1992. Uniconazole effect on growth and chlorophyll content of pyracantha, photinia, and dwarf burford holly. J. Plant Growth Regulat. 11:143-148.
Frymire, R.M. and J.C. Henderson-Cole. 1992. Effect of uniconazole and limited water on growth, water relations, and mineral nutrition of 'Lalandei' pyracantha. J. Plant Growth Regulat. 11:227-231.

Henderson, J.C. and T.H. Nichols. 1991. Pyracantha coccinea 'Kasan' and 'Lalandei' response to uniconazole and chlormequat chloride. HortScience 26:877-880.

Henry, M.J. 1985. Plant growth regulating activities of sterol and gibberellin biosynthesis inhibitors. Bul. Plant Growth Regulat. Soc. Amer. 13(2):9-11.

Holcomb, E.J., S. Ream, and J. Reed. 1983. The effect of BAS 106, ancymidol, and chlormequat on chrysanthemum and poinsettia. HortScience 18:364-365.

Murray, G.E., K.C. Sanderson, and J.C. Williams. 1986. Application methods and rates of ancymidol on plant height and seed germination of bedding plants. HortScience 21:120-122.

Norcini, J.G. and G.W. Knox. 1989. Response of Ligustrum $\times$ ibolium, Photinia $\times$ fraseri, and Pyracantha koidzumi 'Wonderberry' to XE-1019 and pruning. J. Environ. Hort. 7:126-128.
Shive, J.B. and H.D. Sisler. 1976. Effects of ancymidol (a growth retardant) and triarimol (a fungicide) on the growth, sterols, and gibberellins of Phaseolus vulgaris (L.). Plant Physiol. 57:640-644.

Snell, M. and E. Eysell. 1974. Ancymidol, a new growth regulator for ornamental plants. Proc. Brit. Weed Control Conf. 12: 115-122.

Tschabold, E.E., W.C. Meredith, L.R. Guse, and E.V. Krumkalns. 1975. Ancymidol performance as altered by potting media composition. J. Amer. Soc. Hort. Sci. 100:142-144.

Warren, S.L. 1990. Growth response of 13 container-grown landscape plants to uniconazole. J. Environ. Hort. 8:151-153.

Warren, S.L., F.A. Blazich, and M. Thetford. 1991. Whole-plant response of selected woody landscape species to uniconazole. J. Environ. Hort. 9:163-167.

Wulster, G.J. and T.J. Gianfagna. 1991. Freesia bybrida respond to ancymidol, cold storage of corms, and greenhouse temperatures. HortScience 26:1276-1277. 